\title{
Vascular aging in women: is estrogen the fountain of youth?
}

\author{
Susana Novella ${ }^{1,2}$, Ana Paula Dantas ${ }^{3}$, Gloria Segarra ${ }^{1,2}$, Pascual Medina ${ }^{1,2}$ and Carlos Hermenegildo ${ }^{1,2 *}$ \\ ${ }^{1}$ Departamento de Fisiología, Universitat de València, Valencia, Spain \\ 2 Instituto de Investigación Sanitaria INCLIVA, Hospital Clínico Universitario, Valencia, Spain \\ ${ }^{3}$ Institut D'Investigacions Biomèdiques August Pi i Sunyer and Institut Clínic del Tòrax, Hospital Clinic, Barcelona, Spain
}

\section{Edited by:}

Francesc Jiménez-Altayó, Universitat Autonoma de Barcelona, Spain

\section{Reviewed by:}

Rayna Gonzales, University of Arizona COM Phoenix, USA

Raouf Khalil, Brigham and Women's Hospital, USA

Eduardo Nava, University of

Castilla-La Mancha, Spain

*Correspondence:

Carlos Hermenegildo, Departamento de Fisiología, Facultad de Medicina y Odontología, Universitat de València, Av. Blasco Ibañez, 15, E 46010

Valencia, Spain.

e-mail: carlos.hermenegildo@uv.es
Aging is associated with structural and functional changes in the vasculature, including endothelial dysfunction, arterial stiffening and remodeling, impaired angiogenesis, and defective vascular repair, and with increased prevalence of atherosclerosis. Cardiovascular risk is similar for older men and women, but lower in women during their fertile years. This age- and sex-related difference points to estrogen as a protective factor because menopause is marked by the loss of endogenous estrogen production. Experimental and some clinical studies have attributed most of the protective effects of estrogen to its modulatory action on vascular endothelium. Estrogen promotes endothelial-derived NO production through increased expression and activity of endothelial nitric oxide synthase, and modulates prostacyclin and thromboxane $A_{2}$ release. The thromboxane $A_{2}$ pathway is key to regulating vascular tone in females. Despite all the experimental evidence, some clinical trials have reported no cardiovascular benefit from estrogen replacement therapy in older postmenopausal women. The "Timing Hypothesis," which states that estrogen-mediated vascular benefits occur only before the detrimental effects of aging are established in the vasculature, offers a possible explanation for these discrepancies. Nevertheless, a gap remains in current knowledge of cardiovascular aging mechanisms in women. This review comprises clinical and experimental data on the effects of aging, estrogens, and hormone replacement therapy on vascular function of females. We aim to clarify how menopause and aging contribute jointly to vascular aging and how estrogen modulates vascular response at different ages.

Keywords: endothelium, menopause, estradiol, nitric oxide, vascular protection

\section{INTRODUCTION}

Cardiovascular disease (CVD) is the leading cause of mortality in both men and women in developed countries. Nonetheless, sex-associated differences regarding the age of CVD onset and its progression are observed worldwide. Incidence of CVD in premenopausal women is markedly lower than age-matched men in epidemiological studies (Messerli et al., 1987; Bairey Merz et al., 2006; Shaw et al., 2006). After menopause, however, the incidence is comparable or even higher in women than in men (Lerner and Kannel, 1986; Eaker et al., 1993), making CVD the primary cause of death in postmenopausal women ( 55 versus $43 \%$ in men), exceeding all cancer deaths (Rosamond et al., 2008). The lower CVD risk among fertile women is often attributed to the protective role of estrogens at the vascular level. According to epidemiological observations and extensive basic research, estrogen and other sex steroids have direct cardiovascular benefits. Estrogen modulates a myriad of molecular pathways that improve vascular function, whether at the physiological level or when administered as hormone replacement therapy (HRT; Grodstein et al., 2000, 2001; Miller and Duckles, 2008).

Nevertheless, some clinical studies have questioned the protective value of HRT against vascular disease. Two randomized clinical trials, the Women's Health Initiative (WHI; Rossouw et al.,
2002) and the Heart and Estrogen/Progestin Replacement Study (HERS I and II; Gambacciani et al., 2002), indicate that HRT may increase CVD risk and events in postmenopausal women. The reason for this paradox could be attributable to many patient characteristics, including age.

Although aging occurs progressively in both men and women, the onset of menopause marks a sudden increase in the appearance of aging-associated signs in women, and more specifically in the progress of vascular aging. Information about the role of age and menopause in the development of CVD in women is scarce. This review of clinical and experimental data on the effects of aging, estrogens, and HRT on vascular function of females aims to clarify how menopause and aging contribute jointly to vascular aging and how estrogen modulates vascular response at different ages.

\section{HOW DO ESTROGENS AFFECT VASCULAR FUNCTION?}

The numerous vascular effects of estrogens are triggered by complex genomic and non-genomic mechanisms. They include modulation of vascular function and inflammatory response as well as metabolic and hemodynamic effects. Estradiol, the most abundant and potent estrogen in humans, mainly binds and activates estrogen receptors (ERs). Vascular estrogen signaling involves at least three ERs identified in both vascular smooth muscle and 
endothelium, reinforcing the idea that estrogen has a key role in controlling vascular function. The classical subtypes ER $\alpha$ (Soloff and Szego, 1969) and ER $\beta$ (Kuiper et al., 1996) vary not only in their tissue distributions, but also in their agonist/antagonist profile with respect to several compounds (Cano and Hermenegildo, 2000). These ER subtypes belong to the intracellular receptors classically defined as nuclear ligand-activated transcription factors. Activation of these receptors by the corresponding hormones affects gene expression by acting on estrogen-response elements in the target genes and modulating transcriptional events (Beato et al., 1995). Estrogen binding to $E R \alpha$ and $E R \beta$ regulates gene expression in a time- and tissue-dependent manner, generating controversy about the type of receptor involved in vascular protection (Murphy, 2011). In the cardiovascular system, both ER $\alpha$ and $\operatorname{ER} \beta$ have been identified in the endothelium, smooth muscle cells, adventitia, and adrenergic nerve endings of arteries from various territories and several species, including humans (Karas et al., 1994; Kim-Schulze et al., 1996; Venkov et al., 1996; Register and Adams, 1998). Although it has been reported that cultured endothelial cells do not express ER $\alpha$ (Toth et al., 2009), other investigators have demonstrated the presence of both ER $\alpha$ and ER $\beta$ mRNA in endothelium (Wagner et al., 2001) and data from our group demonstrate the protein expression of both ER $\alpha$ and ER $\beta$ in HUVEC (Sobrino et al., 2009, 2010).

In addition to their classic nuclear location, ER can also target the plasma membrane, enabling estrogen activation of several signaling pathways, including those involved in calcium mobilization (Zhang et al., 1994; Nakajima et al., 1995; Prakash et al., 1999) and the phosphatidylinositol-3-kinase (PI3K) pathway (Hisamoto et al., 2001). A third type of ER, G-protein coupled, and mainly located in the plasma membrane, was initially named GPR30 (Takada et al., 1997), then renamed GPER by the International Union of Basic and Clinical Pharmacology, IUPHAR (Alexander et al., 2008). GPER is expressed in both endothelial and smooth muscle cells of human arteries and veins (Haas et al., 2007; Deschamps and Murphy, 2009). After estrogen binding, GPER activates rapid signaling cascades such as extracellular signalrelated kinase and PI3K (Meyer et al., 2011). Several rapid and non-genomic estrogen effects formerly attributed to $\mathrm{ER} \alpha$ have now been described as GPER-mediated (Prossnitz and Barton, 2011).

The vascular protection conferred by estrogen may be mediated indirectly by its influence on the metabolism of lipoproteins or by a direct action on the modulation of molecular pathways in the vessel wall, and more specifically on endothelial cells (Hermenegildo et al., 2002). Vascular endothelium not only regulates vascular tone through flow-mediated mechanisms, but also confers antithrombotic and antiinflammatory properties to the blood vessel. Nitric oxide (NO), the primary endothelial-derived mediator, is involved in many physiological processes, including vasodilation and inhibition of thrombosis, cell migration, and proliferation (Dudzinski and Michel, 2007; Lamas et al., 2007; Michel and Vanhoutte, 2010). Estrogen is known to increase NO bioavailability by mechanisms that either directly increase $\mathrm{NO}$ generation (Figure 1) or decrease superoxide anion $\left(\mathrm{O}_{2}^{-}\right)$concentration, thereby attenuating $\mathrm{O}_{2}^{-}$-mediated $\mathrm{NO}$ inactivation. Mechanisms involved in estrogen-induced increases in NO availability include: (1) transcriptional stimulation of endothelial NO synthase (eNOS) gene expression (Huang et al., 1997; Sumi and Ignarro, 2003); (2) non-genomic activation of enzyme activity via a PI3K/phosphokinase B (PKB/AKT)-mediated signaling pathway (Hisamoto et al., 2001); (3) increased intracellular free $\mathrm{Ca}^{2+}$ concentration $\left(\left[\mathrm{Ca}^{2+}\right] \mathrm{i}\right)$ in endothelial cells (Rubio-Gayosso et al., 2000); (4) decreased production of asymmetric dimethylarginine (ADMA), the eNOS endogenous inhibitor (Monsalve et al., 2007); and (5) attenuated $\mathrm{O}_{2}^{-}$concentrations (Wassmann et al., 2001; Dantas et al., 2002; Ospina et al., 2002).

Estrogens such as $17 \beta$-estradiol, estrone, and estriol have been described to act as reactive oxygen species (ROS) scavengers by virtue of the hydrogen-donating capacity of their phenolic molecular structure (Halliwell and Grootveld, 1987; Dubey and Jackson, 2001). However, in these studies the direct effect of estrogens as scavengers can only be observed at concentrations above $1 \mu \mathrm{M}$ (Arnal et al., 1996; Kim et al., 1996). Considering that plasma concentrations of estrogen in physiological conditions are within the nanomolar range, it is likely that direct scavenger action is not estrogen's main antioxidant mechanism. Estrogen modulates ROS concentration through a mechanism that involves interaction with its estrogenic nuclear receptors to decrease oxidative proteins and/or increase antioxidant enzymes expression. Many studies have associated changes in estrogen levels with altered levels of antioxidant enzymes including glutathione peroxidase, catalase, and superoxide dismutase (Capel et al., 1981; Robb and Stuart, 2011; Sivritas et al., 2011). Moreover, estrogen modulates $\mathrm{NADH} / \mathrm{NADPH}$ oxidases and $\mathrm{AT}_{1}$ receptor gene expression, both of which are major sources of $\mathrm{O}_{2}^{-}$production (Wassmann et al., 2001; Dantas et al., 2002).

Estrogen also has a modulating effect on constrictive factors and positively upregulates the production of endothelium-derived relaxing factors such as $\mathrm{PGI}_{2}$ (Sobrino et al., 2009, 2010) and the endothelium-derived hyperpolarizing factors (Golding and Kepler, 2001), both of which are important mediators of vascular relaxation in resistance-sized arteries. The beneficial effects of estrogen on the endothelium can be partially explained by an inhibitory effect on the production or action of the cyclooxygenase (COX)-derived vasoconstrictor agents prostaglandin $\mathrm{H}_{2}, \mathrm{PGH}_{2}$, and thromboxane $\mathrm{A}_{2}, \mathrm{TXA}_{2}$ (Davidge and Zhang, 1998; Dantas et al., 1999; Novella et al., 2010), and of endothelin-1 (ET-1; David et al., 2001).

Furthermore, estrogen can interfere with ion channels through non-genomic actions. It regulates contractile responses by a direct modulation of $\mathrm{Ca}^{2+}$ mobilization into the vascular smooth muscle cells. Direct interaction of estradiol with voltage-gated Maxi-K channel subunit beta, which confers higher $\mathrm{Ca}^{2+}$ sensitivity, may modulate vascular smooth muscle (Valverde et al., 1999). Estrogen does not inhibit $\mathrm{Ca}^{2+}$ release from the intracellular stores (Crews and Khalil, 1999; Murphy and Khalil, 1999). However, supraphysiological concentrations of estrogen impede $\mathrm{Ca}^{2+}$ influx from the extracellular space (Han et al., 1995; Crews and Khalil, 1999; Murphy and Khalil, 1999) by inhibiting $\mathrm{Ca}^{2+}$ entry through voltage-gated $\mathrm{Ca}^{2+}$ channels (Freay et al., 1997; Kitazawa et al., 1997; Crews and Khalil, 1999; Murphy and Khalil, 1999). Expression of the L-type $\mathrm{Ca}^{2+}$ channels in cardiac muscle is substantially increased in ER-deficient mice (Johnson et al., 1997), suggesting ER-mediated regulation of $\mathrm{Ca}^{2+}$ mobilization. 


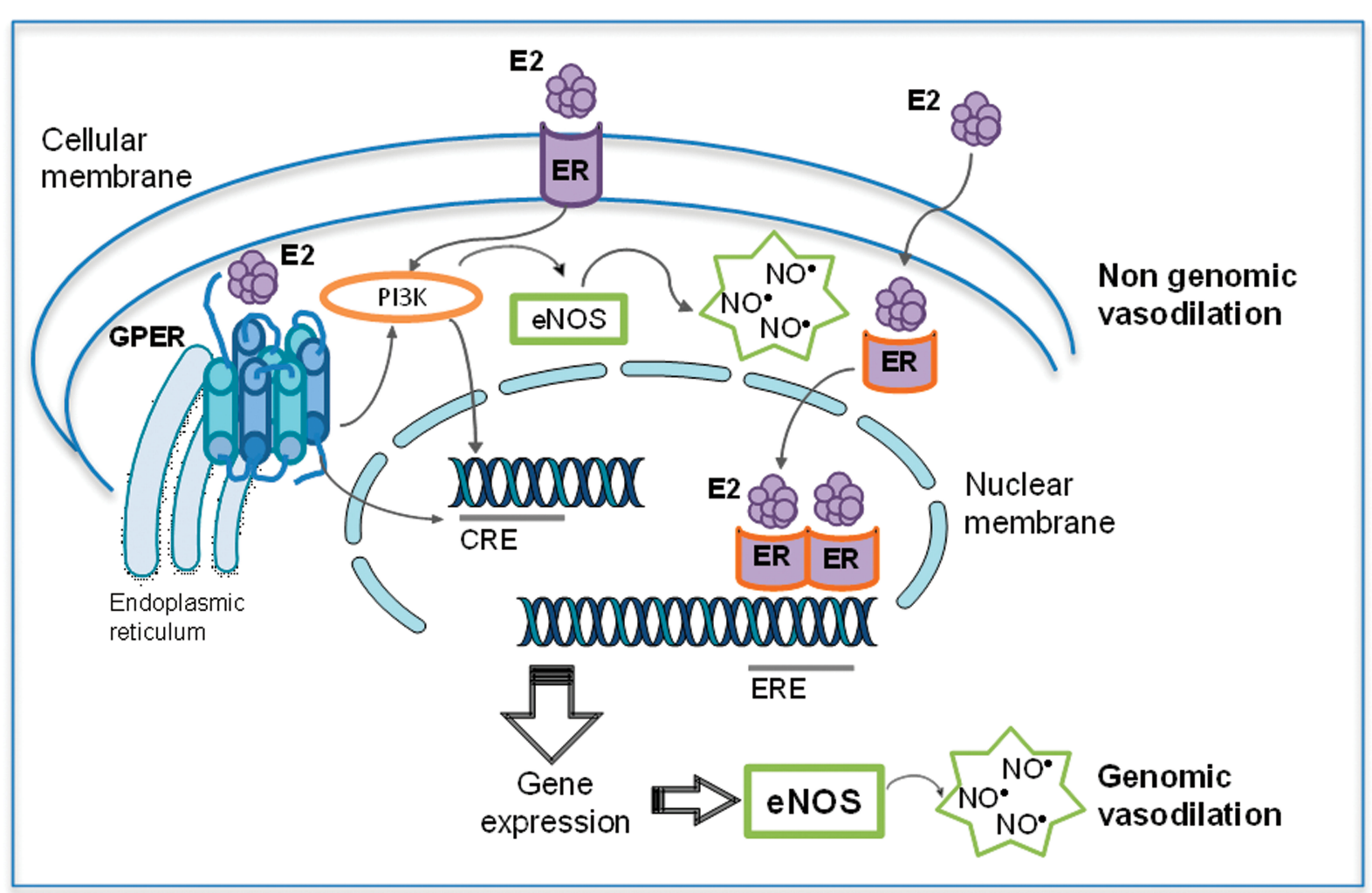

FIGURE 1 | Dual effects of estradiol (E2) on eNOS expression and activity. Estradiol effects on eNOS-mediated nitric oxide (NO) production include both genomic and non-genomic effects. Genomic effects include the classical intracellular estrogen receptors (ER), which after binding of E2 interact with estrogen-response element (ERE) in DNA, resulting in an increased eNOS expression. Moreover, E2 binding to GPER leads to activation of different transcriptional factors such as cAMP response element (CRE) which also induces eNOS expression. Among non-genomic effects, ER and GPER regulate the E2-induced eNOS activity (modified from Sobrino, 2011).
Estrogen also exerts direct modulation on the components of the renin-angiotensin system (RAS), a key regulator of blood pressure and smooth muscle cell growth. Production of angiotensin II (Ang II), the active hormone of the RAS, is reduced by estrogen inhibition of angiotensin-converting enzyme (ACE) expression. In animal models of menopause and in postmenopausal women, chronic estrogen replacement reduces ACE activity in the circulation and in tissues including the kidney and aorta (Brosnihan et al., 1999; Seely et al., 2004). Furthermore, estrogen attenuates expression of and tissue response to type 1 angiotensin receptor $\left(\mathrm{AT}_{1}\right)$ in the aorta, heart, and kidney (Silva-Antonialli et al., 2000; Wu et al., 2003).

\section{THE PROCESS OF VASCULAR AGING: HOW ARE FEMALES AFFECTED?}

Vascular aging is associated with endothelial dysfunction, arterial stiffening and remodeling, impaired angiogenesis, defective vascular repair, and an increasing prevalence of atherosclerosis (Lakatta and Levy, 2003; Erusalimsky, 2009). Aging-associated changes in structure and function of large elastic arteries are seen even in the absence of clinical CVD (Moreau et al., 2003). Although aging per se has detrimental effects in the vasculature, the lack of estrogen due to menopause may add an aggravating CVD risk factor in women, compared to arterial aging in men.
In middle-aged females, aging-associated vascular dysfunction is potentiated by lack of estrogen due to menopause or ovariectomy and improves with estrogen replacement (Harman, 2004; Stice et al., 2009; Novella et al., 2010). Unfortunately, the onset of menopause coincides with a time when aging-associated damage may be noted, making it particularly difficult to distinguish between the contributions of aging and the lack of estrogen.

Vascular aging is a natural phenomenon that could be simply described as a consequence of physical stress, beginning early in life. Arteries are elastic tissues, susceptible to fatigue, and fracture over time as a consequence of extension-relaxation cycles during heartbeats (Avolio et al., 1983). In cross-sectional studies, postmenopausal females taking HRT have less arterial stiffness than their non-treated peers (Moreau et al., 2003; Sumino et al., $2005,2006)$. Radial artery distensibility fluctuates in accordance with estrogen levels during menstrual cycles (Giannattasio et al., 1999). Basic research using animal models of estrogen withdrawal and aging suggests a modulatory role for estrogen in the molecular mechanisms to prevent arterial stiffening (Zhang et al., 2000). A recent study reported that HRT improves arterial compliance, an effect related in part to estrogen actions in the control of endothelial-dependent vasodilatory tone (Moreau et al., 2012). Collagen and elastin content of arterial walls is a key factor in arterial thickening and stiffening. It is mostly regulated by matrix 
metalloproteinases (MMP), enzymes capable of degrading components of the extracellular matrix. During aging, MMP activity decreases markedly, collagen accumulates, and stiffening increases. Estrogen replacement in ovariectomized rats increases MMP activity and restores aged arteries to structural properties similar to those of younger animals studied (Zhang et al., 2000).

Aging is also associated with biochemical changes implicated in CVD development and progression. Dysfunction of both endothelial and smooth muscle molecular signaling appears during the aging process and favors vasospasm, thrombosis, inflammation, and abnormal cell migration and proliferation (Lakatta and Levy, 2003; Briones et al., 2005; Barton, 2010; Herrera et al., 2010). Endothelial dysfunction in the elderly has been associated with malfunctioning of vascular tissue, resulting in atherosclerosis, hypertension, and coronary artery disease (Lakatta and Levy, 2003; Herrera et al., 2010), renal dysfunction (Schmidt et al., 2001; Erdely et al., 2003), and Alzheimer disease (Price et al., 2004). In women, a slight age-related decrease in endothelium-dependent relaxation persists until middle age (around 50 years). After that, the declining response to the endothelium-dependent vasodilator hastens, even exceeding the rate experienced by men (Taddei et al., 1996).

The mechanisms for age-associated endothelial dysfunction are multiple, although most are associated with decreased NO bioavailability (Hayashi et al., 2008; Santhanam et al., 2008; Erusalimsky, 2009; Kim et al., 2009). Reduced endothelium-dependent and NO-mediated vasodilation has been described in both human and animal models of aging (Kim et al., 2009; Virdis et al., 2010). Lower NO production in the elderly may be based on decreased NO synthesis or increased NO degradation. Suggested mechanisms to explain reduced NO production include: (1) decreased expression of eNOS (Briones et al., 2005; Yoon et al., 2010); (2) a lack of NO precursor (L-arginine; Santhanam et al., 2008) and eNOS cofactor tetrahydrobiopterin $\left(\mathrm{BH}_{4}\right.$; Yoshida et al., 2000; Eskurza et al., 2005; Meyer et al., 2011); and (3) increased endogenous eNOS inhibitor ADMA (Xiong et al., 2001; Kielstein et al., 2003). On the other hand, strong evidences support the hypothesis that age-associated increase in oxidative stress and consequent production of $\mathrm{O}_{2}^{-}$is a potent contributor to lower $\mathrm{NO}$ bioavailability and increased endothelial dysfunction (Jacobson et al., 2007; Rodriguez-Manas et al., 2009). There is little information to correlate the progression of aging with the production/degradation of $\mathrm{NO}$ in women. Although several studies have described decreased expression of eNOS in senile female rats and mice (Wynne et al., 2004; Novensa et al., 2011), aging-associated effects on eNOS in women can be easily confounded with the effects of lack of estrogen, since most of these studies grouped women into just two time-points: premenopausal and menopausal groups.

Even though the decline in NO bioavailability could sufficiently explain most of the changes in the functioning of vascular cells, other molecules crucial to control of vascular function are also modified by aging. In the regulation of vascular tone, COX-derived factors are particularly important as they can induce both vascular relaxation $\left(\mathrm{PGI}_{2}\right)$ and contraction $\left(\mathrm{TXA}_{2}\right.$ and $\left.\mathrm{PGH}_{2}\right)$. Some studies have reported a prevalence in the production of relaxing $\mathrm{COX}$ factors in the vasculature of young and healthy individuals (Tang and Vanhoutte, 2008). With aging, COX-dependent vasoconstrictors production becomes evident, leading to increased vascular contraction (Taddei et al., 1997; Rodriguez-Manas et al., 2009). However, the COX isoform involved in the generation of contractile prostanoids remains unclear. In functional studies developed in femoral arteries of aged rats, oxygen free radicals participate in the augmented endothelium-dependent contractions mediated by COX-derived prostanoids. Both the constitutive and inducible isoforms of COX contribute to this endothelial dysfunction (Shi et al., 2008). Molecular studies performed in endothelial cells from aged rats showed an increase in mRNA levels of COX-1, COX2 , and other enzymes involved in the synthesis of prostanoids (Tang and Vanhoutte, 2008), demonstrating the importance of the arachidonic acid-COX cascade in the endothelial and vascular dysfunction associated with aging. Moreover, functional studies have demonstrated an interaction between NO and prostanoids pathways. In aorta from aged female mice, NO bioavailability increases when the COX pathway is inhibited; both gene and protein expression of COX-1 are increased (Novella et al., 2011). Furthermore, activation of inflammatory pathways in the vascular wall plays a central role in the process of vascular aging.

Even in the absence of traditional risk factors for atherosclerosis, an age-associated shift to a proinflammatory gene expression profile, known as endothelial activation, induces upregulation of cellular adhesion molecules and cytokines, which increases endothelial-leukocyte interactions and permeability, mechanisms considered crucial to initial steps in the development of atherosclerosis (Herrera et al., 2010; Seals et al., 2011). Accordingly, a sex-associated difference in inflammatory responses during aging has been proposed. Inflammatory atherosclerosis and associated acute coronary heart disease develop earlier in life in men than in women (Roger et al., 2011) and are associated with earlier death, although men and women present the same overall plaque burden (Frink, 2009). In animal models of atherosclerosis, male sex contributes to a faster and more severe progression of lipid deposition, remodeling, and aortic lesions (Pereira et al., 2010; Surra et al., 2010).

\section{COULD ESTROGEN DECREASE VASCULAR AGING IN WOMEN?}

With the wide-ranging data from experimental research, estrogens might appear to promise protection against the progression of vascular aging and CVD in women. Epidemiological observational studies also suggest that postmenopausal women on HRT are less likely to develop CVD than non-users at the same age (Grodstein et al., 2000, 2001) Nevertheless, these studies contrast with the large prospective clinical trials, HERS and WHI, which failed to show reduced cardiovascular events in postmenopausal women on HRT. In fact, WHI suggested that HRT was associated with increased risk to the cardiovascular system (Rossouw et al., 2002). Possible reasons for this discrepancy have been extensively discussed and include the average age of women entering most HRT clinical trials, 65 years and older, which results in a study population with some degree of aging-associated vascular damage. In addition, participants had been estrogen-deficient for an average of 10 years before starting HRT, a relatively late start that could modify the status of ERs and molecular signaling so as to attenuate the benefits of estrogen. For instance, during aging ERs can undergo posttranslational modifications such as methylation, 
which decreases their expression and activity. We recently reported that aging contributes to increased DNA methylation in female mice aorta, which could be associated with the decrease in the modulatory effects of estrogen (Novensa et al., 2011). A few clinical studies also provide evidence for aging-associated dysregulation of ER methylation and suggest that focal epigenetic changes in ER could contribute to decreased estrogen activity and to the development of atherosclerosis in elderly women (Post et al., 1999; Kim et al., 2007).

Detailed examination of WHI data reveals that early initiation of estrogen replacement produces more favorable results than the later average initiation employed in the WHI studies overall (Grodstein et al., 2006; Rossouw et al., 2007; Prentice et al., 2009). These findings, together with observational studies, have led scientists to create the so-called "timing hypothesis" that estrogenmediated benefits to prevent CVD only occur when treatment is initiated before the detrimental effects of aging are established on vascular walls (Harman, 2006). These effects include endothelial dysfunction and pathophysiological actions, such as increased vascular calcification and generalized stiffening of the arterial tree that increase the prevalence of hypertension and atherosclerosis (Lakatta and Levy, 2003; Erusalimsky, 2009; Kovacic et al., 2011).

Little information is available on whether and how vascular effects of estrogen are modified with aging in females. Aging has been associated with significant reductions in the direct estrogenmediated mechanisms of vascular relaxation (Wynne et al., 2004; LeBlanc et al., 2009; Lekontseva et al., 2010) and inflammation (Pechenino et al., 2011). The lack of estrogen responses in these animal studies was not related to age-associated changes in the plasma levels of estrogen or activity of ER, but rather to possible age-related changes in estrogen-mediated signaling pathways in the vasculature. Modifications in the ratio between $\operatorname{ER} \alpha$ and $\mathrm{ER} \beta$ in older female mice are associated with the lack of protective effects of estrogen on NO production and with a reversal in its antioxidant effect to a pro-oxidant profile (Novensa et al., 2011). Moreover, clinical studies have revealed that CVD risk factors in postmenopausal women were lower among women aged 50-59 years at HRT initiation (Manson et al., 2007; Sherwood et al., 2007). These studies clearly establish the complexity of estrogen effects, which may be influenced by pathophysiological conditions

\section{REFERENCES}

Alexander, S. P., Mathie, A., and Peters, J. A. (2008). Guide to receptors and channels (GRAC), 3rd edition. $\mathrm{Br}$. J. Pharmacol. 153(Suppl. 2), S1-S209.

Arnal, J. F., Clamens, S., Pechet, C., Negre-Salvayre, A., Allera, C., Girolami, J. P., Salvayre, R., and Bayard, F. (1996). Ethinylestradiol does not enhance the expression of nitric oxide synthase in bovine endothelial cells but increases the release of bioactive nitric oxide by inhibiting superoxide anion production. Proc. Natl. Acad. Sci. U.S.A. 93, 4108-4113.

Avolio, A. P., Chen, S. G., Wang, R. P., Zhang, C. L., Li, M. F., and O'Rourke,
M. F. (1983). Effects of aging on changing arterial compliance and left ventricular load in a northern Chinese urban community. Circulation 68, 50-58.

Bairey Merz, C. N., Shaw, L. J., Reis, S. E., Bittner, V., Kelsey, S. F., Olson, M., Johnson, B. D., Pepine, C. J., Mankad, S., Sharaf, B. L., Rogers, W. J., Pohost, G. M., Lerman, A., Quyyumi, A. A., and Sopko, G. (2006). Insights from the NHLBIsponsored women's ischemia syndrome evaluation (WISE) study: part II: gender differences in presentation, diagnosis, and outcome with regard to gender-based pathophysiology of atherosclerosis and including aging and subclinical CVD. Despite convincing arguments by the followers of the "timing hypothesis" the potential extrapolation of the protective effects of estrogen replacement, well described in young females, to older women remains controversial. The field still lacks detailed experimental and clinical research on the long-term effects of estrogen and how it modulates cardiovascular function during aging.

\section{CONCLUSION AND FUTURE DIRECTION}

Our society is aging progressively, and increased life expectancy enhances the risks for diseases associated with the natural fatigue of the body, including CVD. Despite this undeniable reality, there is evidence that vascular aging in women does not follow the same chronology as in men. The vascular protective effects exerted by estrogens have been proposed as the major reason for reduced signs of vascular aging and CVD risk in premenopausal women, compared to men. When natural estrogen withdrawal occurs and a woman enters her climacteric stage, effects of sudden vascular aging become evident, leading to vascular dysfunction and increased risk of a cardiovascular event. The lack of crucial information from clinical trials and the discrepancies in the available data on the regulation of the female cardiovascular system can lead to inappropriate diagnosis and treatment of CVD in older women. Women have been treated like men, despite the notable sex-associated differences in the elements of aging and disease processes. Much research effort is still needed to understand ageand sex-related differences in cardiovascular control, establish the impact of the menstrual cycle and HRT on vascular function, and propose new therapeutic strategies to improve CVD diagnosis and treatment and the overall management of vascular senescence in women.

\section{ACKNOWLEDGMENTS}

Supported by the Spanish Ministerio de Ciencia e Innovación, Instituto de Salud Carlos III -FEDER-ERDF (grants FIS 06/0589, FIS 08/0176 and PI10/00518 and Red HERACLES RD06/0009/0005), and Consellería de Sanidad, Generalitat Valenciana (grants AP 097/2011, AP 104/2011, and GE 027/2011). The authors appreciate the review of English grammar and usage by Elaine Lilly, Ph.D. (Writer's First Aid). macrovascular and microvascular coronary disease. J. Am. Coll. Cardiol. 47, S21-S29.

Barton, M. (2010). Obesity and aging: determinants of endothelial cell dysfunction and atherosclerosis. Pflugers Arch. 460, 825-837.

Beato, M., Herrlich, P., and Schutz, G. (1995). Steroid hormone receptors: many actors in search of a plot. Cell 83, 851-857.

Briones, A. M., Montoya, N., Giraldo, J., and Vila, E. (2005). Ageing affects nitric oxide synthase, cyclooxygenase and oxidative stress enzymes expression differently in mesenteric resistance arteries. Auton. Autacoid Pharmacol. 25, 155-162.
Brosnihan, K. B., Senanayake, P. S., Li, P., and Ferrario, C. M. (1999). Bi-directional actions of estrogen on the renin-angiotensin system. Braz. J. Med. Biol. Res. 32, 373-381.

Cano, A., and Hermenegildo, C. (2000). Modulation of the oestrogen receptor: a process with distinct susceptible steps. Hum. Reprod. Update 6, 207-211.

Capel, I. D., Jenner, M., Williams, D. C., Donaldson, D., and Nath, A. (1981). The effect of prolonged oral contraceptive steroid use on erythrocyte glutathione peroxidase activity. J. Steroid Biochem. 14, 729-732. 
Crews, J. K., and Khalil, R. A. (1999). Antagonistic effects of 17b-estradiol, progesterone, and testosterone on $\mathrm{Ca}^{2+}$ entry mechanisms of coronary vasoconstriction. Arterioscler. Thromb. Vasc. Biol. 19, 1034-1040.

Dantas, A. P., Scivoletto, R., Fortes, Z. B., Nigro, D., and Carvalho, M. H. (1999). Influence of female sex hormones on endothelium-derived vasoconstrictor prostanoid generation in microvessels of spontaneously hypertensive rats. Hypertension 34, 914-919.

Dantas, A. P., Tostes, R. C., Fortes, Z. B., Costa, S. G., Nigro, D., and Carvalho, M. H. (2002). In vivo evidence for antioxidant potential of estrogen in microvessels of female spontaneously hypertensive rats. Hypertension 39, 405-411.

David, F. L., Carvalho, M. H., Cobra, A. L., Nigro, D., Fortes, Z. B., Reboucas, N. A., and Tostes, R. C. (2001). Ovarian hormones modulate endothelin1 vascular reactivity and mRNA expression in DOCA-salt hypertensive rats. Hypertension 38, 692-696.

Davidge, S. T., and Zhang, Y. (1998). Estrogen replacement suppresses a prostaglandin $\mathrm{H}$ synthasedependent vasoconstrictor in rat mesenteric arteries. Circ. Res. 83, 388-395.

Deschamps, A. M., and Murphy, E. (2009). Activation of a novel estrogen receptor, GPER, is cardioprotective in male and female rats. Am. J. Physiol. Heart Circ. Physiol. 297, H1806-H1813.

Dubey, R. K., and Jackson, E. K. (2001). Estrogen-induced cardiorenal protection: potential cellular, biochemical, and molecular mechanisms. Am. J. Physiol. Renal Physiol. 280, F365F388.

Dudzinski, D. M., and Michel, T. (2007). Life history of eNOS: partners and pathways. Cardiovasc. Res. 75, 247-260.

Eaker, E. D., Chesebro, J. H., Sacks, F. M., Wenger, N. K., Whisnant, J. P., and Winston, M. (1993). Cardiovascular disease in women. Circulation 88, 1999-2009.

Erdely, A., Greenfeld, Z., Wagner, L., and Baylis, C. (2003). Sexual dimorphism in the aging kidney: effects on injury and nitric oxide system. Kidney Int. 63, 1021-1026.

Erusalimsky, J. D. (2009). Vascular endothelial senescence: from mechanisms to pathophysiology. J. Appl. Physiol. 106, 326-332.

Eskurza, I., Myerburgh, L. A., Kahn, Z. D., and Seals, D. R. (2005). Tetrahydrobiopterin augments endothelium-dependent dilatation in sedentary but not in habitually exercising older adults. J. Physiol. 568, 1057-1065.

Freay, A. D., Curtis, S. W., Korach, K. S., and Rubanyi, G. M. (1997). Mechanism of vascular smooth muscle relaxation by estrogen in depolarized rat and mouse aorta. Role of nuclear estrogen receptor and $\mathrm{Ca}^{2+}$ uptake. Circ. Res. 81, 242-248.

Frink, R. J. (2009). Gender gap, inflammation and acute coronary disease: are women resistant to atheroma growth? Observations at autopsy. J. Invasive Cardiol. 21, 270-277.

Gambacciani, M., Rosano, G. M., Monteleone, P., Fini, M., and Genazzani, A. R. (2002). Clinical relevance of the HERS trial. Lancet 360, 641.

Giannattasio, C., Failla, M., Grappiolo, A., Stella, M. L., Del, B. A., Colombo, M., and Mancia, G. (1999). Fluctuations of radial artery distensibility throughout the menstrual cycle. Arterioscler. Thromb. Vasc. Biol. 19, 1925-1929.

Golding, E. M., and Kepler, T. E. (2001). Role of estrogen in modulating EDHF-mediated dilations in the female rat middle cerebral artery. Am. J. Physiol. Heart Circ. Physiol. 280, H2417-H2423.

Grodstein, F., Manson, J. E., Colditz, G. A., Willett, W. C., Speizer, F. E., and Stampfer, M. J. (2000). A prospective, observational study of postmenopausal hormone therapy and primary prevention of cardiovascular disease. Ann. Intern. Med. 133, 933-941.

Grodstein, F., Manson, J. E., and Stampfer, M. J. (2001). Postmenopausal hormone use and secondary prevention of coronary events in the nurses' health study. A prospective, observational study. Ann. Intern. Med. 135, 1-8.

Grodstein, F., Manson, J. E., and Stampfer, M. J. (2006). Hormone therapy and coronary heart disease: the role of time since menopause and age at hormone initiation. J. Womens Health (Larchmt.) 15, 35-44.

Haas, E., Meyer, M. R., Schurr, U., Bhattacharya, I., Minotti, R., Nguyen, H. H., Heigl, A., Lachat, M., Genoni, M., and Barton, M. (2007). Differential effects of 17beta-estradiol on function and expression of estrogen receptor alpha, estrogen receptor beta, and GPR30 in arteries and veins of patients with atherosclerosis. Hypertension 49, 1358-1363.

Halliwell, B., and Grootveld, M. (1987). The measurement of free radical reactions in humans. Some thoughts for future experimentation. FEBS Lett. 213, 9-14.
Han, S. Z., Karaki, H., Ouchi, Y., Akishita, M., and Orimo, H. (1995). 17b-Estradiol inhibits $\mathrm{Ca}^{2+}$ influx and $\mathrm{Ca}^{2+}$ release induced by thromboxane A2 in porcine coronary artery. Circulation 91, 2619-2626.

Harman, S. M. (2004). What do hormones have to do with aging? What does aging have to do with hormones? Ann. N. Y. Acad. Sci. 1019, 299-308.

Harman, S. M. (2006). Estrogen replacement in menopausal women: recent and current prospective studies, the WHI and the KEEPS. Gend. Med. 3, 254-269.

Hayashi, T., Yano, K., Matsui-Hirai, H., Yokoo, H., Hattori, Y., and Iguchi, A. (2008). Nitric oxide and endothelial cellular senescence. Pharmacol. Ther. 120, 333-339.

Hermenegildo, C., Garcia-Martinez, M. C., Tarin, J. J., and Cano, A. (2002). Inhibition of low-density lipoprotein oxidation by the pure antiestrogens ICI 182780 and EM-652 (SCH 57068). Menopause 9, 430-435.

Herrera, M. D., Mingorance, C., Rodriguez-Rodriguez, R., and Alvarez de Sotomayor, M. (2010). Endothelial dysfunction and aging: an update. Ageing Res. Rev. 9, 142-152.

Hisamoto, K., Ohmichi, M., Kurachi, H., Hayakawa, J., Kanda, Y., Nishio, Y., Adachi, K., Tasaka, K., Miyoshi, E., Fujiwara, N., Taniguchi, N., and Murata, Y. (2001). Estrogen induces the Akt-dependent activation of endothelial nitric-oxide synthase in vascular endothelial cells. J. Biol. Chem. 276, 3459-3467.

Huang, A., Sun, D., Kaley, G., and Koller, A. (1997). Estrogen maintains nitric oxide synthesis in arterioles of female hypertensive rats. Hypertension 29, 1351-1356.

Jacobson, A., Yan, C., Gao, Q., RinconSkinner, T., Rivera, A., Edwards, J., Huang, A., Kaley, G., and Sun, D. (2007). Aging enhances pressureinduced arterial superoxide formation. Am. J. Physiol. Heart Circ. Physiol. 293, H1344-H1350.

Johnson, B. D., Zheng, W., Korach, K. S., Scheuer, T., Catterall, W. A., and Rubanyi, G. M. (1997). Increased expression of the cardiac L-type calcium channel in estrogen receptordeficient mice. J. Gen. Physiol. 110, 135-140.

Karas, R. H., Patterson, B. L., and Mendelsohn, M. E. (1994). Human vascular smooth muscle cells contain functional estrogen receptor. Circulation 89, 1943-1950.

Kielstein, J. T., Bode-Boger, S. M. Frolich, J. C., Ritz, E., Haller, H., and Fliser, D. (2003). Asymmetric dimethylarginine, blood pressure, and renal perfusion in elderly subjects. Circulation 107, 1891-1895.

Kim, J., Kim, J. Y., Song, K. S., Lee, Y. H., Seo, J. S., Jelinek, J., GoldschmidtClermont, P. J., and Issa, J. P. (2007). Epigenetic changes in estrogen receptor beta gene in atherosclerotic cardiovascular tissues and invitro vascular senescence. Biochim. Biophys. Acta 1772, 72-80.

Kim, J. H., Bugaj, L. J., Oh, Y. J., Bivalacqua, T. J., Ryoo, S., Soucy, K. G., Santhanam, L., Webb, A., Camara, A., Sikka, G., Nyhan, D., Shoukas, A. A., Ilies, M., Christianson, D. W., Champion, H. C., and Berkowitz, D. E. (2009). Arginase inhibition restores NOS coupling and reverses endothelial dysfunction and vascular stiffness in old rats. J. Appl. Physiol. 107, 1249-1257.

Kim, Y. D., Chen, B., Beauregard, J., Kouretas, P., Thomas, G., Farhat, M. Y., Myers, A. K., and Lees, D. E. (1996). 17b-Estradiol prevents dysfunction of canine coronary endothelium and myocardium and reperfusion arrhythmias after brief ischemia/reperfusion. Circulation 94, 2901-2908.

Kim-Schulze, S., McGowan, K. A. Hubchak, S. C., Cid, M. C., Martin, M. B., Kleinman, H. K., Greene, G. L. and Schnaper, H. W. (1996). Expression of an estrogen receptor by human coronary artery and umbilical vein endothelial cells. Circulation 94, 1402-1407.

Kitazawa, T., Hamada, E., Kitazawa, K., and Gaznabi, A. K. (1997). Non-genomic mechanism of $17 \mathrm{~b}$ oestradiol-induced inhibition of contraction in mammalian vascular smooth muscle. J. Physiol. 499, 497-511.

Kovacic, J. C., Moreno, P., Nabel, E. G., Hachinski, V., and Fuster, V. (2011). Cellular senescence, vascular disease, and aging: part 2 of a 2-part review: clinical vascular disease in the elderly. Circulation 123, 1900-1910.

Kuiper, G. G., Enmark, E., Pelto-Huikko, M., Nilsson, S., and Gustafsson, J. A. (1996). Cloning of a novel receptor expressed in rat prostate and ovary. Proc. Natl. Acad. Sci. U.S.A. 93, 5925-5930.

Lakatta, E. G., and Levy, D. (2003). Arterial and cardiac aging: major shareholders in cardiovascular disease enterprises: part I: aging arteries: a "set up" for vascular disease. Circulation 107, 139-146.

Lamas, S., Lowenstein, C. J., and Michel, T. (2007). Nitric oxide signaling 
comes of age: 20 years and thriving. Cardiovasc. Res. 75, 207-209.

LeBlanc, A. J., Reyes, R., Kang, L. S., Dailey, R. A., Stallone, J. N., Moningka, N. C., and Muller-Delp, J. M. (2009). Estrogen replacement restores flow-induced vasodilation in coronary arterioles of aged and ovariectomized rats. Am. J. Physiol. Regul. Integr. Comp. Physiol. 297, R1713-R1723.

Lekontseva, O. N., Rueda-Clausen, C. F., Morton, J. S., and Davidge, S. T. (2010). Ovariectomy in aged versus young rats augments matrix metalloproteinase-mediated vasoconstriction in mesenteric arteries. Menopause 17, 516-523.

Lerner, D. J., and Kannel, W. B. (1986). Patterns of coronary heart disease morbidity and mortality in the sexes: a 26-year follow-up of the Framingham population. Am. Heart J. 111, 383-390.

Manson, J. E., Allison, M. A., Rossouw, J. E., Carr, J. J., Langer, R. D., Hsia, J., Kuller, L. H., Cochrane, B. B., Hunt, J. R., Ludlam, S. E., Pettinger, M. B., Gass, M., Margolis, K. L., Nathan, L., Ockene, J. K., Prentice, R. L., Robbins, J., and Stefanick, M. L. (2007). Estrogen therapy and coronary-artery calcification. N. Engl. J. Med. 356, 2591-2602.

Messerli, F. H., Garavaglia, G. E., Schmieder, R. E., Sundgaard-Riise, K., Nunez, B. D., and Amodeo, C. (1987). Disparate cardiovascular findings in men and women with essential hypertension. Ann. Intern. Med. 107, 158-161.

Meyer, M. R., Prossnitz, E. R., and Barton, M. (2011). The G protein-coupled estrogen receptor GPER/GPR30 as a regulator of cardiovascular function. Vascul. Pharmacol. 55, 17-25.

Michel, T., and Vanhoutte, P. M. (2010). Cellular signaling and NO production. Pflugers Arch. 459, 807-816.

Miller, V. M., and Duckles, S. P. (2008). Vascular actions of estrogens: functional implications. Pharmacol. Rev. 60, 210-241.

Monsalve, E., Oviedo, P. J., GarciaPerez, M. A., Tarin, J. J., Cano, A., and Hermenegildo, C. (2007). Estradiol counteracts oxidized LDLinduced asymmetric dimethylarginine production by cultured human endothelial cells. Cardiovasc. Res. 73, 66-72.

Moreau, K. L., Donato, A. J., Seals, D. R., DeSouza, C. A., and Tanaka, H. (2003). Regular exercise, hormone replacement therapy and the agerelated decline in carotid arterial compliance in healthy women. Cardiovasc. Res. 57, 861-868.

Moreau, K. L., Meditz, A., Deane, K., and Kohrt, W. M. (2012). Tetrahydrobiopterin improves endothelial function and decreases arterial stiffness in estrogen-deficient postmenopausal women. Am. J. Physiol. Heart Circ. Physiol. 302, H1211-H1218.

Murphy, E. (2011). Estrogen signaling and cardiovascular disease. Circ. Res. 109, 687-696.

Murphy, J. G., and Khalil, R. A. (1999). Decreased $\left[\mathrm{Ca}^{2+}\right]$ i during inhibition of coronary smooth muscle contraction by 17b-estradiol, progesterone, and testosterone. J. Pharmacol. Exp. Ther. 291, 44-52.

Nakajima, T., Kitazawa, T., Hamada E., Hazama, H., Omata, M., and Kurachi, Y. (1995). 17b-Estradiol inhibits the voltage-dependent Ltype $\mathrm{Ca}^{2+}$ currents in aortic smooth muscle cells. Eur. J. Pharmacol. 294, 625-635.

Novella, S., Dantas, A. P., Segarra, G., Novensa, L., Bueno, C., Heras, M., Hermenegildo, C., and Medina, P. (2010). Gathering of aging and estrogen withdrawal in vascular dysfunction of senescent accelerated mice. Exp. Gerontol. 45, 868-874.

Novella, S., Dantas, A. P., Segarra, G., Novensa, L., Heras, M., Hermenegildo, C., and Medina, P. (2011). Aging enhances contraction to thromboxane $\mathrm{A}(2)$ in aorta from female senescence-accelerated mice. Age (Dordr.). (in press).

Novensa, L., Novella, S., Medina, P., Segarra, G., Castillo, N., Heras, M., Hermenegildo, C., and Dantas, A. P. (2011). Aging negatively affects estrogens-mediated effects on nitric oxide bioavailability by shifting ERalpha/ERbeta balance in female mice. PLoS ONE 6, e25335. doi:10.1371/journal.pone.0025335

Ospina, J. A., Krause, D. N., and Duckles, S. P. (2002). 17b-estradiol increases rat cerebrovascular prostacyclin synthesis by elevating cyclooxygenase-1 and prostacyclin synthase. Stroke 33, 600-605.

Pechenino, A. S., Lin, L., Mbai, F. N., Lee, A. R., He, X. M., Stallone, J. N., and Knowlton, A. A. (2011). Impact of aging vs. estrogen loss on cardiac gene expression: estrogen replacement and inflammation. Physiol. Genomics 43, 1065-1073.

Pereira, T. M., Nogueira, B. V., Lima, L. C., Porto, M. L., Arruda, J. A., Vasquez, E. C., and Meyrelles, S. S. (2010). Cardiac and vascular changes in elderly atherosclerotic mice: the influence of gender. Lipids Health Dis. 9, 87.

Post, W. S., Goldschmidt-Clermont, P. J., Wilhide, C. C., Heldman, A. W., Sussman, M. S., Ouyang, P., Milliken, E. E., and Issa, J. P. (1999). Methylation of the estrogen receptor gene is associated with aging and atherosclerosis in the cardiovascular system. Cardiovasc. Res. 43, 985-991.

Prakash, Y. S., Togaibayeva, A. A., Kannan, M. S., Miller, V. M., Fitzpatrick, L. A., and Sieck, G. C. (1999). Estrogen increases $\mathrm{Ca}^{2+}$ efflux from female porcine coronary arterial smooth muscle. Am. J. Physiol. 276, H926-H934.

Prentice, R. L., Manson, J. E., Langer, R. D., Anderson, G. L., Pettinger, M., Jackson, R. D., Johnson, K. C. Kuller, L. H., Lane, D. S., WactawskiWende, J., Brzyski, R., Allison, M., Ockene, J., Sarto, G., and Rossouw, J. E. (2009). Benefits and risks of postmenopausal hormone therapy when it is initiated soon after menopause. Am. J. Epidemiol. 170, 12-23.

Price, J. M., Hellermann, A., Hellermann, G., and Sutton, E. T. (2004). Aging enhances vascular dysfunction induced by the Alzheimer's peptide beta-amyloid. Neurol. Res. 26 305-311.

Prossnitz, E. R., and Barton, M. (2011). The G-protein-coupled estrogen receptor GPER in health and disease. Nat. Rev. Endocrinol. 7, 715-726.

Register, T. C., and Adams, M. R. (1998). Coronary artery and cultured aortic smooth muscle cells express mRNA for both the classical estrogen receptor and the newly described estrogen receptor beta. J. Steroid Biochem. Mol. Biol. 64, 187-191.

Robb, E. L., and Stuart, J. A. (2011). Resveratrol interacts with estrogen receptor-beta to inhibit cell replicative growth and enhance stress resistance by upregulating mitochondrial superoxide dismutase. Free Radic. Biol. Med. 50, 821-831.

Rodriguez-Manas, L., El-Assar, M. Vallejo, S., Lopez-Doriga, P., Solis, J., Petidier, R., Montes, M., Nevado, J., Castro, M., Gomez-Guerrero, C., Peiro, C., and Sanchez-Ferrer, C. F. (2009). Endothelial dysfunction in aged humans is related with oxidative stress and vascular inflammation. Aging Cell 8, 226-238.

Roger, V. L., Go, A. S., Lloyd-Jones, D. M., Adams, R. J., Berry, J. D., Brown, T. M., Carnethon, M. R., Dai, S., de, S. G., Ford, E. S., Fox, C. S., Fullerton, H. J., Gillespie, C., Greenlund, K. J., Hailpern, S. M., Heit, J. A., Ho, P. M., Howard, V. J., Kissela, B. M., Kittner, S. J., Lackland, D. T., Lichtman,
J. H., Lisabeth, L. D., Makuc, D. M., Marcus, G. M., Marelli, A., Matchar, D. B., McDermott, M. M., Meigs, J. B., Moy, C. S., Mozaffarian, D., Mussolino, M. E., Nichol, G., Paynter, N. P., Rosamond, W. D., Sorlie, P. D., Stafford, R. S., Turan, T. N., Turner, M. B., Wong, N. D., and Wylie-Rosett, J. (2011). Heart disease and stroke statistics - 2011 update: a report from the American Heart Association. Circulation 123, e18-e209.

Rosamond, W., Flegal, K., Furie, K., Go, A., Greenlund, K., Haase, N., Hailpern, S. M., Ho, M., Howard, V., Kissela, B., Kittner, S., LloydJones, D., McDermott, M., Meigs, J., Moy, C., Nichol, G., O’Donnell, C., Roger, V., Sorlie, P., Steinberger, J., Thom, T., Wilson, M., and Hong, Y. (2008). Heart disease and stroke statistics - 2008 update: a report from the American Heart Association Statistics Committee and Stroke Statistics Subcommittee. Circulation 117, e25-e146.

Rossouw, J. E., Anderson, G. L., Prentice, R. L., LaCroix, A. Z., Kooperberg, C., Stefanick, M. L., Jackson, R. D., Beresford, S. A., Howard, B. V., Johnson, K. C., Kotchen, J. M., and Ockene, J. (2002). Risks and benefits of estrogen plus progestin in healthy postmenopausal women: principal results from the women's health initiative randomized controlled trial. JAMA 288, 321-333.

Rossouw, J. E., Prentice, R. L., Manson, J. E., Wu, L., Barad, D., Barnabei, V. M., Ko, M., LaCroix, A. Z., Margolis, K. L., and Stefanick, M. L. (2007). Postmenopausal hormone therapy and risk of cardiovascular disease by age and years since menopause. JAMA 297, 1465-1477.

Rubio-Gayosso, I., Sierra-Ramirez, A., Garcia-Vazquez, A., MartinezMartinez, A., Munoz-Garcia, O., Morato, T., and Ceballos-Reyes, G. (2000). 17b-estradiol increases intracellular calcium concentration through a short-term and nongenomic mechanism in rat vascular endothelium in culture. $J$. Cardiovasc. Pharmacol. 36, 196-202.

Santhanam, L., Christianson, D. W., Nyhan, D., and Berkowitz, D. E. (2008). Arginase and vascular aging. J. Appl. Physiol. 105, 1632-1642.

Schmidt, R. J., Beierwaltes, W. H., and Baylis, C. (2001). Effects of aging and alterations in dietary sodium intake on total nitric oxide production. Am. J. Kidney Dis. 37, 900-908.

Seals, D. R., Jablonski, K. L., and Donato, A. J. (2011). Aging and vascular 
endothelial function in humans. Clin. Sci. 120, 357-375.

Seely, E. W., Brosnihan, K. B., Jeunemaitre, X., Okamura, K., Williams, G. H., Hollenberg, N. K., and Herrington, D. M. (2004). Effects of conjugated oestrogen and droloxifene on the renin-angiotensin system, blood pressure and renal blood flow in postmenopausal women. Clin. Endocrinol. (Oxf.) 60, 315-321.

Shaw, L. J., Bairey Merz, C. N., Pepine, C. J., Reis, S. E., Bittner, V., Kelsey, S. F., Olson, M., Johnson, B. D., Mankad, S., Sharaf, B. L., Rogers, W. J., Wessel, T. R., Arant, C. B., Pohost, G. M., Lerman, A., Quyyumi, A. A., and Sopko, G. (2006). Insights from the NHLBIsponsored women's ischemia syndrome evaluation (WISE) study: part I: gender differences in traditional and novel risk factors, symptom evaluation, and genderoptimized diagnostic strategies. J. Am. Coll. Cardiol. 47, S4-S20.

Sherwood, A., Bower, J. K., McFetridgeDurdle, J., Blumenthal, J. A., Newby, L. K., and Hinderliter, A. L. (2007). Age moderates the short-term effects of transdermal 17b-estradiol on endothelium-dependent vascular function in postmenopausal women. Arterioscler. Thromb. Vasc. Biol. 27, 1782-1787.

Shi, Y., Man, R. Y., and Vanhoutte, P. M. (2008). Two isoforms of cyclooxygenase contribute to augmented endothelium-dependent contractions in femoral arteries of 1-year-old rats. Acta Pharmacol. Sin. 29, 185-192.

Silva-Antonialli, M. M., Fortes, Z. B., Carvalho, M. H., Scivoletto, R., and Nigro, D. (2000). Sexual dimorphism in the response of thoracic aorta from SHRs to losartan. Gen. Pharmacol. 34, 329-335.

Sivritas, D., Becher, M. U., Ebrahimian, T., Arfa, O., Rapp, S., Bohner, A., Mueller, C. F., Umemura, T., Wassmann, S., Nickenig, G., and Wassmann, K. (2011). Antiproliferative effect of estrogen in vascular smooth muscle cells is mediated by Kruppellike factor-4 and manganese superoxide dismutase. Basic Res. Cardiol. 106, 563-575.

Sobrino, A. (2011). New Expression Pathways Regulated by Estradiol in Human Endothelial Cells. Doctoral Thesis. University of Valencia.

Sobrino, A., Mata, M., LagunaFernandez, A., Novella, S., Oviedo, P. J., Garcia-Perez, M. A., Tarin, J. J., Cano, A., and Hermenegildo,
C. (2009). Estradiol stimulates vasodilatory and metabolic pathways in cultured human endothelial cells. PLoS ONE 4, e8242. doi:10.1371/journal.pone.0008242

Sobrino, A., Oviedo, P. J., Novella, S., Laguna-Fernandez, A., Bueno, C., Garcia-Perez, M. A., Tarin, J. J., Cano, A., and Hermenegildo, C. (2010). Estradiol selectively stimulates endothelial prostacyclin production through estrogen receptor\{alpha\}. J. Mol. Endocrinol. 44, 237-246.

Soloff, M. S., and Szego, C. M. (1969). Purification of estradiol receptor from rat uterus and blockade of its estrogen-binding function by specific antibody. Biochem. Biophys. Res. Commun. 34, 141-147.

Stice, J. P., Eiserich, J. P., and Knowlton, A. A. (2009). Role of aging versus the loss of estrogens in the reduction in vascular function in female rats. Endocrinology 150, 212-219.

Sumi, D., and Ignarro, L. J. (2003). Estrogen-related receptor alpha 1 up-regulates endothelial nitric oxide synthase expression. Proc. Natl. Acad. Sci. U.S.A. 100, 14451-14456.

Sumino, H., Ichikawa, S., Kasama, S., Kumakura, H., Takayama, Y., Sakamaki, T., and Kurabayashi, M. (2005). Effect of transdermal hormone replacement therapy on carotid artery wall thickness and levels of vascular inflammatory markers in postmenopausal women. Hypertens. Res. 28, 579-584.

Sumino, H., Ichikawa, S., Kasama, S., Takahashi, T., Kumakura, H., Takayama, Y., Kanda, T., and Kurabayashi, M. (2006). Different effects of oral conjugated estrogen and transdermal estradiol on arterial stiffness and vascular inflammatory markers in postmenopausal women. Atherosclerosis 189, 436-442.

Surra, J. C., Guillen, N., rbones-Mainar, J. M., Barranquero, C., Navarro, M. A., Arnal, C., Orman, I., Segovia, J. C., and Osada, J. (2010). Sex as a profound modifier of atherosclerotic lesion development in apolipoprotein E-deficient mice with different genetic backgrounds. J. Atheroscler. Thromb. 17, 712-721.

Taddei, S., Virdis, A., Ghiadoni, L., Magagna, A., and Salvetti, A. (1997). Cyclooxygenase inhibition restores nitric oxide activity in essential hypertension. Hypertension 29, 274-279.

Taddei, S., Virdis, A., Ghiadoni, L., Mattei, P., Sudano, I., Bernini,
G., Pinto, S., and Salvetti, A. (1996). Menopause is associated with endothelial dysfunction in women. Hypertension 28, 576-582.

Takada, Y., Kato, C., Kondo, S., Korenaga, R., and Ando, J. (1997). Cloning of cDNAs encoding G protein-coupled receptor expressed in human endothelial cells exposed to fluid shear stress. Biochem. Biophys. Res. Commun. 240, 737-741.

Tang, E. H., and Vanhoutte, P. M. (2008). Gene expression changes of prostanoid synthases in endothelial cells and prostanoid receptors in vascular smooth muscle cells caused by aging and hypertension. Physiol. Genomics 32, 409-418.

Toth, B., Scholz, C., Saadat, G., Geller, A., Schulze, S., Mylonas, I., Friese, K., and Jeschke, U. (2009). Estrogen receptor modulators and estrogen receptor beta immunolabelling in human umbilical vein endothelial cells. Acta Histochem. 111, 508-519.

Valverde, M. A., Rojas, P., Amigo, J., Cosmelli, D., Orio, P., Bahamonde, M. I., Mann, G. E., Vergara, C., and Latorre, R. (1999). Acute activation of Maxi$\mathrm{K}$ channels (hSlo) by estradiol binding to the beta subunit. Science 285 , 1929-1931.

Venkov, C. D., Rankin, A. B., and Vaughan, D. E. (1996). Identification of authentic estrogen receptor in cultured endothelial cells. A potential mechanism for steroid hormone regulation of endothelial function. Circulation 94, 727-733.

Virdis, A., Ghiadoni, L., Giannarelli, C. and Taddei, S. (2010). Endothelial dysfunction and vascular disease in later life. Maturitas 67, 20-24.

Wagner, A. H., Schroeter, M. R. and Hecker, M. (2001). 17betaestradiol inhibition of NADPH oxidase expression in human endothelial cells. FASEB J. 15, 2121-2130.

Wassmann, S., Baumer, A. T., Strehlow, K., van Eickels, M., Grohe, C., Ahlbory, K., Rosen, R., Bohm, M. and Nickenig, G. (2001). Endothelial dysfunction and oxidative stress during estrogen deficiency in spontaneously hypertensive rats. Circulation 103, 435-441.

Wu, Z., Maric, C., Roesch, D. M., Zheng, W., Verbalis, J. G., and Sandberg, K. (2003). Estrogen regulates adrenal angiotensin AT1 receptors by modulating AT1 receptor translation. Endocrinology 144, 3251-3261.

Wynne, F. L., Payne, J. A., Cain, A. E., Reckelhoff, J. F., and Khalil, R.
A. (2004). Age-related reduction in estrogen receptor-mediated mechanisms of vascular relaxation in female spontaneously hypertensive rats. Hypertension 43 , 405-412.

Xiong, Y., Yuan, L. W., Deng, H. W., Li, Y. J., and Chen, B. M. (2001). Elevated serum endogenous inhibitor of nitric oxide synthase and endothelial dysfunction in aged rats. Clin. Exp. Pharmacol. Physiol. 28, 842-847.

Yoon, H. J., Cho, S. W., Ahn, B. W., and Yang, S. Y. (2010). Alterations in the activity and expression of endothelial NO synthase in aged human endothelial cells. Mech. Ageing Dev. 131, 119-123.

Yoshida, Y. I., Eda, S., and Masada M. (2000). Alterations of tetrahydrobiopterin biosynthesis and pteridine levels in mouse tissues during growth and aging. Brain Dev. 22(Suppl. 1), S45-S49.

Zhang, F., Ram, J. L., Standley, P. R., and Sowers, J. R. (1994). 17b-Estradiol attenuates voltage-dependent $\mathrm{Ca}^{2+}$ currents in $\mathrm{A} 7 \mathrm{r} 5$ vascular smooth muscle cell line. Am. J. Physiol. 266, C975-C980.

Zhang, Y., Stewart, K. G., and Davidge, S. T. (2000). Estrogen replacement reduces age-associated remodeling in rat mesenteric arteries. Hypertension 36, 970-974.

Conflict of Interest Statement: The authors declare that the research was conducted in the absence of any commercial or financial relationships that could be construed as a potential conflict of interest.

Received: 31 January 2012; accepted: 08 May 2012; published online: 06 June 2012.

Citation: Novella S, Dantas AP, Segarra G, Medina P and Hermenegildo C (2012) Vascular aging in women: is estrogen the fountain of youth? Front. Physio. 3:165. doi: 10.3389/fphys.2012.00165

This article was submitted to Frontiers in Vascular Physiology, a specialty of Frontiers in Physiology.

Copyright (c) 2012 Novella, Dantas, Segarra, Medina and Hermenegildo. This is an open-access article distributed under the terms of the Creative Commons Attribution Non Commercial License, which permits non-commercial use, distribution, and reproduction in other forums, provided the original authors and source are credited. 